\title{
Market Power Abuse in EU And UK: A Review of Consumer Detriment Issues
}

\author{
Afroza Bilkis* and Supravat Halder**
}

\begin{abstract}
When a dominant company exploits its market power and that harms fair competition in the marketplace, average consumers remain in the most vulnerable condition having vital influence on but no active participation in the functioning of the market. The actions of a business that has market power can have serious effects on the operation of a market. An undertaking in a dominant position may use its market power in several ways, the most common being exploiting consumers by artificial scarcity and increasing prices. Moreover, there may be diverse interpretation as to the nature of an undertaking while considering market power abuse cases for the purposes of European Union (EU) Competition law. It is significant to consider the status of consumers in a market to see if dominant entities are abusing their powers and therefore test the level of commercialization.
\end{abstract}

\section{Introduction}

Focus of this study is on market power abuse perspectives in both UK and EU. The central idea of this study revolves around increased commercialization that results in increased commercial tolerance of the consumers that is detrimental to their rights. Provisions regulating market power abuse and dominance as covered under the Treaty on the Functioning of the European Union (TFEU) emphasize that dominant market powers are mostly involved in abusive practices and their responsibility for fair practice in the market could define competition scenario.

The question therefore arises that in the complex area of Competition Law, what exactly is the position of the consumers. Should they consider market power abuse as a basic violation of their rights? Or, have the dominating entities managed, by this time, to raise commercialization to that extent where consumers are, voluntarily or involuntarily, left to tolerate the abuse?

\footnotetext{
*Assistant Professor and Head, Department of Law, Northern University Bangladesh. She may be reached at bilkis360@gmail.com

** Lecturer, Department of Law, University of Barisal. He may be reached at haldersupravat@gmail.com
} 


\section{Objective of the study}

This paper explores the extent of market power abuse and its impact on consumer rights protection with particular reference to the fast-growing commercial tolerance and ensuring consumer rights in a competitive market. Besides giving a better understanding of the status of consumers with respect to market power abuse, this study, it is hoped, will identify and test the efficacy of the established legal and regulatory frameworks. The study will become significant as it will progress with judging commercial tolerance issues. For example - different views of consumers may lead abuse cases towards unlikely conclusions in similar market conditions. Younger consumers in today's retail climate do not equate private label goods with lower quality. ${ }^{1}$ Rather they see them as cheaper equals to branded goods. ${ }^{2}$

\section{Market Power Abuse and Consumer Detriment in EU and UK: Conceptual Issues}

\subsection{The Concept of Market Power are not supposed to have any market}

Theoretically commercial firms and organizations power or dominance. Under competition law, this is known as 'pure/ perfect competition' theory that stands against economic issues of monopoly, cartels and mergers. According to Investopedia dictionary ${ }^{3}$, 'perfect competition' is a theoretical market structure which is opposite to monopoly. Such a market condition offers consumers flexibility with supplies as there are more buyers and sellers in the market.

In economics, monopoly is a market condition where one company or undertaking occupies $100 \%$ or almost $100 \%$ of the relevant market. ${ }^{4}$ Cartels are secret agreements between or among producers that may effectively steal from consumers by fixing high prices while mergers are union of two companies where the more powerful one takes over the other one to reduce competition in the market. ${ }^{5}$ In microeconomics (the branch of economics that studies the contribution of groups of consumers or firms, or of individual consumers, to a country's economy ${ }^{6}$, a commercial entity is said to be a market power when it has the strength to influence the price, production, supply or demand of products and services ${ }^{7}$. It can become a price maker in the market. The

\footnotetext{
${ }^{1}$ Gorrie, Alastair, Competition between branded and private label goods. Do competition concerns arise when a customer is also a competitor? European Competition Law Review, E.C.L.R. 2006, 27(5),

217-227.

${ }^{2}$ Ibid.

${ }^{3}$ www.investopedia.com last accessed on.....

${ }^{4}$ See Rodger, Barry J and Macculloch, Angus, Competition Law and Policy in The EC and UK ( ${ }^{\text {th }}$ Ed.), Routledge. Cavendish, 2009 Chap. 1

${ }^{5}$ Ibid.

${ }^{6}$ Bloomsbury Business Library - Business \& Management Dictionary. 2007, p4774-4774. 1p. Available at http://web.b.ebscohost.com.ergo.glam.ac.uk Last accessed on 28.09.2014.

${ }^{7}$ See Market Power, Investopedia Dictionary, Available at http://www.investopedia.com Last accessed on 10.04.2014.
} 
general way of measuring whether a particular organization possesses market power or not, is to see if it has significant influence in setting price of products in the market while ensuring its own market share. Manipulation of supply and demand also results in setting of price.

\subsection{Abuse of Market Power}

The corner stone law regulating market power abuse in the European Union is the Treaty on The Functioning of The European Union (TFEU). It is immediately apparent that the prohibition on abuse of dominance covers a wide and diverse range of corporate behaviour ${ }^{8}$. The European Court of Justice (ECJ) has also played a historical role in the evolution of the concept of market power abuse.

However, market power abuse should be defined from an objective point of view. When any undertaking having substantial power in the market uses such power with the intention of eliminating or damaging its competitors or preventing similar businesses to enter into the market, it constitutes an abuse. In some jurisdictions, this behaviour is also referred as 'misuse of market power' ${ }^{9}$. On the other hand, it is to be noted that neither having market power nor using it is illegal. What is illegal is to carry out the conducts in market in such a way or for a purpose that contravenes the relevant competition law.

\subsection{Consumer Detriment}

The basic idea about consumer protection law is to regulate the relationship between consumers and businesses regarding the sale of goods and services. As such consumer protection law can cover a wide range of business liabilities including unfair practices and product liability.

In the UK, several laws have been adopted for the regulation of consumer protection such as - Consumer Credit Act 1974, Unfair Contract Terms Act 1977, Unfair Terms in Consumer Contract Regulations 1999, and Unfair Contract Terms Bill. All these laws complement the requirements of EU Directives on Consumer Protection 2011/ 83/ EU. Although primarily consumer rights violation cases fell within the areas of tort or contract, developments in judicial and international approach have widened the scope even to cover criminal liabilities.

Under Art. 2 of the Unfair Commercial Practices Directives of 2005 and as interpreted by the European Court of Justice, an average consumer are a reasonably well-informed, reasonably observant and a circumspect person. This definition is given taking into consideration of the social, cultural and linguistic factors.

\footnotetext{
${ }^{8}$ Vickers, John, Speech to the $31^{\text {st }}$ Conference of the European Association for Research in Industrial Economics, Berlin, 3 September 2004, p.3.

${ }^{9}$ See Misuse of Market Power, Australian Competition and Consumer Commission, Available at http://www.accc.gov.au Last accessed on 10.04.2014.
} 
According to the European Commission Notice on the Application of Art $81^{10}$, the concept of consumers encompasses all direct or indirect users of the products covered by the agreement, including producers that use the products as an input, wholesalers, retailers and final consumers.

The term 'consumer detriment' has, however, a wider meaning than consumer rights violation under different provisions of law. 'Consumer detriment' not only includes violation of consumer rights but also covers any market practice that would not be reasonably expected by consumers. The term, to be discussed in connection with market practice, may be said to include all business behaviour that causes consumers to be uninformed or misinformed about the market, products and services.

\subsection{Measuring Consumer Detriment}

While estimating consumer detriment in a given market, it is to be noted that such detriment should not be measured in terms of policy application or implementation in the market. Rather when detriment is suspected, the following methods may be considered and applied: ${ }^{11}$

(a) Define the appropriate product and geographic market;

(b) Assess whether companies have market power in the relevant market, which in turn requires analysis of the market structure and whether there are barriers to entry;

(c) Examine the conduct of companies, to determine whether and how they are exercising market power;

(d) Estimate the loss to consumers.

This approach is acceptable from the view point of market power abuse and its impact on consumer rights protection.

\section{Market Power Abuse: Issues regarding Commercial Tolerance}

It is a common economic and practical idea that consumers will get what they need to irrespective of the market condition, in particular, price of products. It cannot be said that the price level regulates the choice of consumers and even the highest price offered for a particular product in the market may not discourage all or average consumers. The question is then how the use of market power and commercial tolerance of consumers are correlated.

\footnotetext{
${ }^{10}$ Now Art. 101 of TFEU, EC 2004, O.J.C 101/97.

${ }^{11}$ Europe Economics, An Analysis of the Issue of Consumer detriment and the most appropriate methodologies to estimate it, Report for DG SANCO, July 2007, p.218-219.
} 


\subsection{The Correlation between market Power and Commercial tolerance by consumers}

The correlation between market power and commercial tolerance can be said to lie in the fact that a brand name and its functions and offers in the market largely affect the choice of consumers and thus the flow of products and services in the market. Average consumers are likely to be psychologically compelled by brands, i.e. dominant entities in the market. At present, most consumers are aware of brands and they tend to brand their own identity through the products they use. Lasseron ${ }^{12}$ has suggested that branding of personal identity through brand features of products and services is now central to our lives. Thus consumption defines a fast increasing tendency in consumers to shape their individual personalities.

For average consumers, price tolerance is not zero and very often ... a seller could get away with some price increase without serious consideration of the competition or the short run effects on demand. ${ }^{13}$ It happens because a dominant power in the market somehow manages to make the differences between its own and other alternative products, clear to the consumers and thus gets benefit from such price increase.

Therefore, commercializing products and services more may not always affect the tolerance of consumers. In cases of particular products and services, for example, luxury goods, it is believed that a consumer would not normally expect any remarkable decrease of price. On the contrary, average consumers are more likely to doubt the worth or standard of a product or service if the price goes down than the ordinary charge for it. According to Kirby, Meaning and Warren ${ }^{14}$, despite falls in consumer wages, the recent GDP growth in UK has been principally driven by consumer spending that contributed $1.6 \%$ growth to the GDP in 2013. The authors also believe that consumer spending will remain the key driver of any economic recovery in 2014 and 2015 as well. Thus, consumers can be price reluctant. Another important question thus arises -'why do consumers accept the so called commercialization by dominant business entities?' The answer could be anything but there are some basic economic drives of demand and supply which the dominant powers in the market may apply in their business strategies to remain in power and rule over the market and consumers. A group of consumers will prefer to buy a large amount of products at a lower price than to buy a few of them for higher price. Another group will prefer to buy a product at a higher price and with a brand name

\footnotetext{
${ }^{12}$ Lasseron, Emille, Branding Identity and Tolerance, 2005, Available at www.brie.berkeley.edu Last accessed on 29 September 2014.

${ }^{13}$ See for more discussion Nwokoye, Nonyelu G., An Experimental Study of the Relationship Between Responses to price Changes and the Price Level For Shoes, NA- advances in Consumer Research, 1975, Volume 02, eds. Mary Jane Schlinger, Ann Abor, MI : Association for Consumer Research, pp. 693704.

${ }^{14}$ See Abrami, Regina M., William C. Kirby, and F. Warren McFarlan. Can China Lead? Reaching the Limits of Power and Growth. Harvard Business Review Press, 2014.
} 
attached to it than its alternative offered by a non-brand company assuming that the better quality product has the higher price. Thus price elasticity is not material for all consumers. Sometimes they are even ready to buy large quantity of products at higher price.

However, research has shown that at supermarkets, when price is increased at $1 \%$, the demand goes down to $2 \%{ }^{15}$ This is particularly true for the group of consumers who ordinarily look for the cheap products and services. They can be termed as 'price sensitive'. In a recent report of March, 2013, Business Insider ${ }^{16}$ has advised that even in the USA and Europe, smartphone buyers are price sensitive.

Furthermore, sometimes price reluctance or price sensitivity do not have such great impact on commercial tolerance as that of domestic demands of a country. For example- Germany, despite being a country of price sensitive consumers, is one of the largest importers in Europe. Germany has imported 1170,000 tonnes of vegetables from the Netherlands in 2013. ${ }^{17}$

Thus, it is not easy to determine the demand of a particular product or service in the market as the amount of demand depends on each consumer's demand and as a consumer can fall in any of the categories stated above. The economic consideration and the psychology of consumers regarding product quality could even vary from time to time and then it would be difficult even to categorize them. The dominant powers in the market are capable of offering different prices and target all groups of consumers at a time. They have enough resources for market research and fast development of strategies. Though this behavior cannot be theoretically said to be abusive, the obvious impact of this behavior will restrict competition in the market significantly. Another aspect to consider is what economic consideration is compelling business organizations to use their market power and excessively materialize consumer demands. The European market is becoming more and more dependent on domestic consumption rather than international trading and investment. ${ }^{18}$ For UK as well Europe is the main export market for goods but the market is flat now and until it picks up domestic demand will be the main motor of growth. ${ }^{19}$

\footnotetext{
${ }^{15}$ See for more details Price and Competition in Food Markets, Publication of University of Southern California, Available at http://www.consumerspsycholoist.com/food Price and Competition.html Last accessed on 21.05.2014.

${ }^{16}$ www.businessinsider.com

${ }^{17}$ Hans-Christoph Behr, AMI: "Trends are organic, local and convenience" "Germany is price sensitive but Europe's largest import market" Available at http://www.freshplaza.com Last accessed on 28 September 2014.

${ }^{18}$ See McRae, Hamish, We need to spend for a happy Christmas, City Comment, Business, The London Evening Standard on 16/12/2013, p.42.

19 Ibid.
} 
It also attracts some consideration that commercial tolerance of consumers can sometimes be purely psychological. For a group of consumers, greater amount of possessions brings greater pleasure. As research has found, UK is a place of hugely energetic and innovative shoppers. This is why services like online orders, home deliveries and special instructions to retailers or service providers are very common now a days. Retail shopping here is favorite among consumers and they are more interested in online shopping. Nearly 13\% of all retail sales in 2012 in UK were online, which is the highest in Europe, and higher even than the US at around $9 \% .^{20}$ This over dependence of consumers on retail shopping gives the dominant powers in the market the opportunity to escape their liability for price rigidity and other ways of restricting competition in the market. It is a defense for them that the consumers are still buying products and services and thus the demand is still on and fast growing.

Unfortunately, a basic established practice in competition is that resources should be allocated where they are valued most. As per Maiese ${ }^{21}$, this is contradictory with distributive justice that is concerned with fair allocation of resources among diverse members of the community. As the brand names are valued by most consumers, it is believed by average consumers that they will find what they need if they visit a supermarket or a so called brand shop. The good or evil side of competition in the market lies in the fact that competition will always drive out inefficient businesses from the market. The brands not only manage to separate themselves from their rivals but also distinguish their products in unique ways to convince the consumers. ${ }^{22}$

A dominant power in the market will try to remain in power at all times and in fact there are some systems in law which may indirectly assist them to commercialize their products more than the expected market price. For example- if a business organization has a license to supply a particular product within a particular local area having no competitor, it is actually establishing a monopoly of the supply of that product in that area. The consideration of local consumers here will be to get the product from this supplier than to travel and bear more costs to get it from elsewhere even though the price may be lower there. For instance- if a consumer has to spend $£ 1.50$ travel cost to get a product worth $£ 1.20$ from elsewhere than the local shop, they will definitely prefer to buy it for $£ 2.20$ from the local shop. This way, the monopolists in the market gets away with their abusive practices. Though from ordinary point of view this may not seem abusive, but in the competition perspectives, it is because the same standard of the product might be offered at a considerably higher price but with some sort of convenience.

\footnotetext{
${ }^{20}$ See McRae, Hamish, We need to spend for a happy Christmas, City Comment, Business, The London Evening Standard on 16/12/2013, p.42.

${ }^{21}$ Maiese, Michelle, distributive justice, (Originally published in June 2003; updated in June 2013 by Heidi Burgess), Available at http://www.beyondintractability.org Last accessed on 26 September 2014.

${ }^{22}$ See for more Boyes, William, Managerial Economics Markets and the Firm (2 ${ }^{\text {nd }}$ ed.) 2012, South Western Cengage Learning, p. 186.
} 
Brand names and goodwill in the market have the power to generate something more than just commoditization. It can generate special features that people would see in the products and services. A good example is Starbucks. Starbucks has been able to offer to its consumers the price for a cup of coffee that is double the actual cost of providing it. People going to Starbucks believe that the wide variety of choices of drinks that it offers cannot be duplicated by other coffee shops. The eminence gained by Starbucks will remain as such as long as it is able to hold on to the value that the consumers put on it. ${ }^{23}$ Thus, consumers valuing a brand name are important source of market power for that brand and it is an easy way to commercialize the particular product offered under that brand name.

The other side of commercializing can be predatory pricing which means such reduction in the price which has the ultimate objective of bringing in more profits for the business and damaging the process of competition. A dominant firm reacts to competition in one of its markets, either a geographical or a product market, by cutting price so as to drive the competitor out of business. ${ }^{24}$ Such practice is seen with the aim of maintaining the dominant firm's monopoly in the market. However, when dominant firms offer such low prices, average consumers rush into the stores to grab their needs.

Ofcom, the telecoms regulator in UK, has investigated allegations in 2005 that BT, the telecoms giant, is engaged in predatory pricing in the sale of cordless telephones ${ }^{25}$. It was alleged that BT cut prices on most of its phone sets that gave it a rise up to more than $60 \%$ shares in the relevant market from $40 \%$ within just a period of 18 months. The interesting facts to consider here is how brands such as BT manages to reduce the price in no time and why. The long run outcome of such price cuts can have significant impact on the business process and state revenues. Price cuts are quickly and easily matched by rivals, and once matched they lower revenues for all firms ${ }^{26}$ and defeat the aim of competition law. Competition in market aims at fair dealing by business firms and higher consumer rights protection and not at loss of revenues for the businesses.

There is no doubt about the fact that average consumers are voluntarily or involuntarily subjected to market presentation by the undertakings. So far as consumer rights in the market are concerned, dominant undertakings would design their strategies in a manageable way where they may come into conflict with such rights. This is a well known practice by the brands. In particular in UK, the customer service wings of these brands would offer three or four times the price of product as

\footnotetext{
${ }^{23}$ See for more Boyes, William, Managerial Economics Markets and the Firm (2 ${ }^{\text {nd }}$ ed.) 2012 , South Western Cengage Learning, p. 188.

${ }^{24}$ Furse, Mark, Competition Law of the EC and UK ( $5^{\text {th }}$ ed.), 2006, Oxford University Press, p. 293.

${ }^{25}$ The Telegraph on 22 May, 2005.

${ }^{26}$ Porter, M. E., Competitive Strategy (1980), New York, The Free Press, p.17.
} 
compensation if a product goes wrong and the customer makes complaint. However, the penalty for failure to maintain product standards in law is much higher than this. In some cases, they might be awarded heavy fines or even the business license may be cancelled. This is an example how businesses are capable of escaping their legal liability for operating in the market in the name of customer service.

\section{Dominant Powers and Market Price: The Question of Consumer Protection}

However, it is argued that UK law is less strict in respect of providing consumer protection particularly regarding market practice as it provides some defences to the undertakings that may override consumer protection in proceedings. One such remarkable defence is to see if the practice in question in the market is common in similar businesses. This gives the dominant powers a wide scope for avoiding liability as they have the technical and scientific knowledge to establish a common practice in market. Moreover, they can do it in no time and thereby defeat the purpose of consumer protection.

\subsection{Anti Competitive Merger}

Recently, Fair Search, a group of 17 high tech companies that includes giant businesses like Nokia, Microsoft and Expedia, has brought a claim to the European Competition Commission against Google, the most powerful search engine company ever. The allegation is that Google is monopolizing the search engine market through its Android technology and taking full control over consumer data. The company is reported to have $96 \%$ of the Smartphone data operating system market. What Google has done can be addressed in the legal terminology of 'Anti-competitive merger' that increases the market power of a merging firm.

the European Commission and other regional bodies have been trying hard to harmonize substantive competition law. More recently, the commission has published its Proposals for Revision of European Trade Mark Law, trade marks being a largely disputed area of competition law in EU. The trade marks law in question is known as the Council Directive No. 89/104/EEC (Repealed by EU Directive 2008/95/EC), to approximate the laws of the Member States relating to trade marks. However, both the law and the proposals are highly criticized on grounds that they create more uncertainty. Explaining the complications, $\operatorname{Kur}^{27}$ writes that “... courts must either ignore the (new) law compelling them to find for infringement only where the origin function is affected, or they must assume that (and explain why) trade marks used on genuine goods first marketed outside the EEA do not guarantee to consumer that the goods originate from the trade mark holder...”.

\footnotetext{
${ }^{27}$ Kur, Annette, International Review of Intellectual Property and Competition Law 2014 Trade marks function, don't they? CJEU jurisprudence and unfair competition practices IIC 2014, 45(4), 434-454.
} 


\subsection{Commercialization}

Commercialization is so fast and powerful today that undertakings having considerable market power would sometimes ignore the requirement of competition law to ensure their responsibility of not adopting measures or behaviour that would further disrupt an already poor competitive process in the market. This issue was brought into attention in Microsoft $v$ Commission ${ }^{28}$. It was observed in the case that: "the Commission was correct to find ... that when Microsoft had responded to the letter of 15 September 1998 it had not taken sufficiently into account its special responsibility not to hinder effective and undistorted competition in the common market. He Commission was also correct to state ... that that particular responsibility derived from Microsoft's 'quasi-monopoly' on the client PC operating systems market."

"Even a supplier with a considerable market share may not be in a position to resist a key retailer's demands."

While commercializing for business and goodwill, most undertakings do not consider the need to measure consumer benefits and consumer detriments. Taking note of this situation, the government of UK, in 2004, issued a Consultation paper on consumer strategy that emphasized on considering consumer protection in trade and industry. In the summary of responses to the consultation, the UK Department of Trade and Industry (DTI) said that:

“... respondents identified a need to assess consumer harm fairly in the context of the size of the market... [I] intervention in the borderline cases can have serious unintended consequences...; small-scale economic detriment can impact greatly on low-income consumers."

\subsection{Cartels}

Furthermore, the European Commission Notice on Immunity from Fines and Reduction of Fines in Cartel Cases signifies the fact that several aspects of cartels such as fixing prices, production or sales quotas or sharing markets or acquiring a large share of it creates serious restrictions in international trade, in particular exports and imports. The Commission believes that these:

“... are among the most serious restrictions of competition encountered by the Commission and ultimately result in increased prices and reduced choices for the consumer."

\section{Impact of Market Power Abuse on Consumer Rights}

As argued earlier average consumers are not concerned about what their rights are in a market and that the market practice should be consistent with their rights. Monopoly in the market or abuse of market power can redistribute the economic

${ }^{28}$ Case T- 201/04 Microsoft v Commission [2007] 5 CMLR 11, at para 775. 
benitits of a society by allocating more wealth to the rich class of consumers. A monopoly in the market would normally fix prices and marketing policies which cannot be favourable to all classes of consumers, in particular, average consumers. Rather, only a group of consumers able to afford products and services under any circumstances, can actually Though the purpose of competition law is to support the competition process, nevertheless it cannot be said that ...tools of competition law cannot be used in support of wider social objectives ${ }^{29}$. Protection of consumer rights against abusive market practice is one such social purpose of competition law.

Dominance is a question of fact but generally refers to a large amount of market share by the undertaking in question. As such, courts have been found giving different interpretations as to what may form dominance. Market shares close to even $100 \%$ are evident. In BPB and British Gypsum v Commission ${ }^{30}$, the court found the undertakings having $96-98 \%$ share in the market in UK and $92-100 \%$ in Ireland. However, ...market share will not itself establish an undertaking's dominance but it will be evidence of that organization's strength on that market. ${ }^{31}$ Also, even if an undertaking's market share is or below 50\%, it is necessary to compare its strength with its rivals in the market to determine its dominance.

In a broad sense, market power abuse will hinder or weaken the level of competition in market. It is suggested that some of the practices in market as referred in art. 102 of TFEU may not compulsorily be considered as abusive, but due to such practices by an existing dominant power in the market, an anti-competitive behavior may be established. In British Airways plc v Commission ${ }^{32}$ it was held that:

“... it is not necessary to demonstrate that the abuse in question had a concrete effect on the markets concerned. It is sufficient in that respect to demonstrate that the abusive conduct of the undertaking in a dominant position tends to restrict competition, or in other words, that the conduct is capable of having, or likely to have, such an effect."

Therefore the actual effect of the abusive conduct is not a test to consider if competition in the market is restricted but only the dominant position's ability to prevent competition may be sufficient to establish an infringement under Art. 102 of TFEU. The European court decided almost similar in Michelin v Commission ${ }^{33}$. The court expressed the view that it is an abuse where a dominant undertaking has adopted a business behaviour which is not anti-competitive otherwise but may cause serious concerns when a position of market dominance is held.

\footnotetext{
${ }^{29}$ Furse, Mark, Competition Law of the EC and UK ( $5^{\text {th }}$ ed.), 2006, Oxford University Press, p.248.

${ }^{30}$ 1997, 4 CMLR 238.

${ }^{31}$ Rodger, Barry $\mathrm{J}$ and Macculloch, Angus, Competition Law and Policy in The EC and UK (4 ${ }^{\text {th }}$ Ed.), Routledge. Cavendish, 2009, p. 110-111

${ }^{32}$ 2004, 4 CMLR 19.

${ }^{33}$ 2004, 4 CMLR 923.
} 
Economist Federico Etro, in his paper 'The EU Approach to Abuse of Dominance, 34 written while acting for the Task Force on Competition of The International Chamber of Commerce, advised that the application of EU competition law on abuse of dominance entails identifying a dominant position and its abusive behaviour which is typically connected with excessive pricing or with exclusionary practices as predatory pricing, rebates, tying or bundling, exclusive dealing or refusal to supply. Thus, in order that discussion in this part is clear, two concepts need to be analyzed first, in what ways market power can be abused and second, how such abuses affect consumer rights.

Conducts to prevent competition in the market have a direct effect not only on competition regulation but also on consumers' and buyers' freedom of choice and to operate in the market freely. Such ways can sometimes be indirect, for instance, through exclusive customer agreements. The nature and the structure of such agreements are brought into attention of the judicial bodies and the commission to consider infringement of competition rules.

In commerce, these so called 'fidelity agreements' are regarded as a necessary and safe business technique for undertakings would be assured about supplies and sales. However, such agreements or clauses in the agreements may have the effect of reducing or restricting competition in the market. These agreements can include exemption or limitation clauses for avoiding liability for breach. It is also to be noted that such exclusive agreements can be broadly categorized into two - one, between businesses and the other between business and consumers. Therefore, all such agreements are not inconsistent with consumer protection through any such agreement or clause would affect competition. This has long been recognized in case laws. In Hoffman-La Roche \& Co. AG v Commission ${ }^{35}$, the commission found the conclusion of such an agreement as abusive and when the case went to European Court of Justice, the Court held that:

"An undertaking which is in a dominant position on a market and ties purchasers even if it does so at their request - by an obligation or promise on their part to obtain all or most of their requirements exclusively from the said undertaking abuses its dominant position."

\footnotetext{
${ }^{34}$ See Etro, Federico, The EU Approach to Abuse of Dominance, U.C.S.C. Department of Economics, ECG and INTERTIC ( International Think-tank on Innovation and Competition), Milan, February 2006. Available at www.intertic.org Last accessed on 20.06.2014.

35 1979, 3 CMLR 211.
} 
The European court has been very strict in the application of Art. 102 of TFEU. In the Suiker Unie ${ }^{36}$, the European Court of Justice (ECJ) held that grant of rebates to customers that met their annual requirements exclusively from the dominant undertaking constituted an abuse of a dominant position. ECJ also emphasized that the rebates granted in return for exclusivity were likely to dissuade the dominant undertaking's customers from obtaining their supplies from other producers. Osterud, in his book $^{37}$, suggests that rebate schemes may be designed in various ways depending on the conditions that must be fulfilled for the customer to be entitled to the rebate. He agrees with the ECJ view and mentions that rebates have diverging economic effects. It may grant incentives to customers not to buy products or services from other suppliers and may also make it difficult for its competitors to conduct an adequate amount of operations in the market to remain in competition.

Moreover, it is immaterial under what circumstances such agreements were concluded or arrangements were made. The material thing to see is whether the customer is directly or indirectly compelled to purchase from one undertaking. On the other hand though, considering the provisions of law, the pricing has the direct effect on consumers' and buyers' rights, it is very difficult to apply the tests developed by courts to identify what pricing can be abusive and detrimental to the balanced exercise of such rights. Business undertakings would name such pricing as 'price competition' and would tend to regard it as valid. However, under competition law, it is not legitimate where the undertaking is dominant in the market.

Price discrimination' which is a product of anti-competitive behaviour, has been alleged by Spector ${ }^{38}$ as targeting the new competitors' customers through low prices, more profitably and more frequently. There is no doubt that such pricing is a product of super commercialization and that it affects fair competition and thereby consumer rights. Despite this, the complexity of judicial tests to apply in practical circumstances might not be helpful in determining the link between commercialization through pricing and its effects on market and consumer rights.

In AKZO Chemie BV $v$ Commission ${ }^{39}$, the court articulated an economic test to determine which pricing would have the potential to eliminate competition. The court proposed that if prices of products are below average variable costs, predatory pricing may be presumed.

\footnotetext{
${ }^{36}$ Joined Cases, 40-48, 50, 54-56, 111, 113-114/73, Suiker Unie and others $v$ Commission [1975], ECR 1663 , paras 517-528.

${ }^{37}$ Osterud, Eirik, Identifying Exclusionary Abuses by Dominant Undertakings under EU Competition Law: The Spectrum of Tests, 2010, Kluwer Law International, p.69. For more analysis see also

${ }^{38}$ Spector, David, The Strategic Uses of Price Discrimination, Presented for Swedish Competition Authority, November 18, 2005.

${ }^{39}$ 1993, 5 CMLR 215.
} 
However, it is very difficult to apply this test as what costs should be considered in such respect is a debated issue in economics. For example- why the price of foods in some cases is higher than it is expected, has been addressed by a number of experts on the online debate ${ }^{40}$ over food price in EU. Matteo Bartolini, the president of the European Council of Young Farmers, is of the view that:

“... the reason for high prices, most of the time, is to be found in the long food chain, not in EU regulation." $" 41$

Professor Tim Lang of Food Policy at the London City University also agrees with Bartolini and describes the issue as 'food miles'. On the other hand, Global Food Security $^{42}$, the UK based online food security research institute, thinks that many factors such as production, trade, environmental impact on agriculture, climate change etc can contribute to food prices to a great extent. According to Global Food Security, food price is a global issue and it affects everyone.

\subsection{Impact of consumer perceptions on competition}

Like anti-competitive practices may lead to considerable impact on average consumers, consumer perceptions and product differentiation may also have impact on competition. When consumers distinguish between homogenous products, it becomes difficult for new entrants to enter into competition. This may be caused for a variety of reasons including advertising and reliance upon particular brands. Consequently, the consumer will not consider the new entrant's products and then the new entrant will have to not only compete against the dominant power but it will also have to struggle against such perception. In the United Brands ${ }^{43}$, the Court found that there was no real difference between the branded and unbranded bananas. Despite this, consumers were ready to spend $10 \%$ more for the branded ones on the perception that they were of premium quality.

\subsection{Other impacts}

It is the nature of competition that dominant undertakings would continue to try to get rid of their competitors in the market. Where the undertaking is able to maintain its market share or strength for quite a long time, dominance may be established and ...barriers to entry, which give an insight into potential long term strength, are very important ${ }^{44}$. Barrier to entry is used both in strict and wide sense. In strict sense, it would refer to inefficiency of an undertaking to exist or become successful in the market. However, the wider approach is more connected to competition issues according to which, the existing dominant undertakings would like to see that the

\footnotetext{
${ }^{40}$ Available at www.foodsecurity.ac.uk Last accessed on 29 September 2014.

${ }^{41}$ Ibid.

42 Ibid.

${ }^{43}$ See Case 27/76 United Brands Continental BV v Commission [1978] ECR 207.

${ }^{44}$ Ibid. 111.
} 
potential rivals have largely invested into the market to enter like they did. From an economic point of view, this approach cannot be said unethical but it will restrict new entrants into the market considerably ${ }^{45}$.

Previously, the UK Consumer Protection Act, 1987 created clear provisions for the violation of consumer rights and punishment relating to price of products and services under Part III. Under s. 20 (1) and (2) of the Act, a person would be guilty of an offence if misleading information as to price of products and services is provided to consumers. This Part of the Act is now repealed by the Consumer Protection from Unfair Trading Regulations 2008. The Regulations have however reflected similar provisions in s. 5, 6 and 7. Sec. 5(2) defines commercial practices as misleading by way of either false information provided or deceptive presentation of the products. Sec: 5(4) specifies certain matters relating to commercial practice or the products or services that supplement sec. 5(2) of the Regulations. The Regulations are adopted to implement the Unfair Commercial Practices Directives (UCPD) in UK.

The motives for the commercial practice ${ }^{46}$, the price or the manner in which the price is calculated ${ }^{47}$, the existence of a specific price advantage ${ }^{48}$, the consumer's rights or the risks he may face ${ }^{49}$ are all material facts to consider in relation to misleading commercial practice. Also, according to sec. 6(4) of the Regulations, any fact relating to the price, the tax attached and the manner in which the price is calculated in case the price cannot be calculated in advance are all material. Under sec. 5(2), the test for such commercial practice being misleading is to see if it has an impact on average consumers. Thus, unfair commercial practices by a business can affect consumer rights in different ways. On the other hand, even if the price is not misleading or is correct, still very high prices set by a dominant undertaking is an abuse of its dominant position and will have an effect on consumers.

Under the provisions of UCPD, material distortion in consumer behaviour in the market can be caused by passing on materially inaccurate information on market conditions or by otherwise inducing the consumer to acquire the product at conditions less favourable than normal market conditions ${ }^{50}$. Such market practice would considerably impair the consumer's ability to make an informed decision, thereby causing the consumer to take a transactional decision that he would not have taken otherwise ${ }^{51}$.

\footnotetext{
${ }^{45}$ See for more discussion Stigler, GJ, The Organization of Industry, 1968, Chicago: Chicago UP.

${ }^{46}$ S.5(4)(d).

${ }^{47}$ S.5(4)(g).

${ }^{48}$ S.5(4)(h).

${ }^{49}$ S.5(4)(k).

${ }^{50}$ Art. 4 UCPD.

${ }^{51}$ Rt. 2(e) UCPD.
} 
The broad impact of market power abuse on consumer protection was somewhat ignored until the $21^{\text {st }}$ century pro-consumer concept. The early stages in the development and application of competition law (during $20^{\text {th }}$ century) are seen not as protective as it should have been of consumer rights. Rodger and MacCulloch have stated in their book that this is why during 1990s the UK Competition Commission has been highly criticized regarding their reports that favoured the big businesses as opposed to consumer interests. In 2003, the Commission confirmed that abuse of market power by the dominant undertakings may result in lack of choice of product and relevant information, excessive prices and lack of competition. All these are considered as market failure resulting in consumer detriment.

That there is always an impact on consumers of market practices and failures, can be understood from the fact that under EU and UK regulation of competition law, consumer interest is a pre-requisite in designing appropriate remedies. This is particularly true where the Commission carries out investigation and inquiries under the Enterprise Act of 2002. In investigating into cases of store cards, home credit and banking, the Commission has considered direct financial impact on consumers resulting from lack of effective competition. ${ }^{52}$ The Office of Fair Trading, in its Guideline on Abuse of dominant position ${ }^{53}$, signifies that conducts that exploit consumers are the first category of abusive practices.

A business organization, having market power or dominance, can easily take the advantage of ignorance of consumers and mislead them regarding price and other commercial practices that affect consumer rights. In most of the cases, though the price can be easily figured out, the manner in which the price is calculated cannot be determined in advance.

Rodger and MacCulloch have laid down a good example in this regard. According to them, it is not likely that customers would find a Ferrari 430 and a Mazda MX-5 as competing in the same market ${ }^{54}$. Although, both provide the same function, it cannot be expected that consumers may consider them interchangeable. The material fact that consumers consider in such cases is price of the product.

Also, a monopolist enjoys a quiet life in the relevant market as it does not care about the impacts of its behaviour on consumers and economy. Thus, in Porto di Genova ${ }^{55}$, a port authority refused to apply modern technology in the unloading operations. The Court found that it constituted an abuse as using old methods resulted in longer times to unload the ships and was therefore more expensive.

\footnotetext{
${ }^{52}$ Rodger, Barry J and Macculloch, Angus, Competition Law and Policy in The EC and UK (4 ${ }^{\text {th }}$ Ed.), Routledge. Cavendish, 2009, p. 166.

${ }^{53}$ December 2004.

${ }_{55}^{54}$ At p. 107.

${ }^{55}$ See Case C-179/90 Merci Convenzionali Porto di Genova SpA v Siderurgica Gabrielli [1994] 4 CMLR 422.
} 
Furthermore, an important aspect to consider while assessing the impact of anticompetitive behaviour is to see if the intended use of the product narrows down the market for consumers. This was observed by the European Court in Commercial Solvents $^{56}$. In this case, Commercial Solvents supplied nitropropane to a company for the production of a particular drug. When Commercial Solvents stopped supplying nitropropane, the drug producing company claimed that Commercial Solvents was dominant and was abusing its market power through denial to supply. In defence, Commercial Solvents invoked the availability of other chemicals that it proposed as substitutes for nitropropane.

However, the Court, carefully investigating into the facts, found that the process used by the drug producing company relied solely on supply of nitropropane and other chemicals could not serve its purpose of use. Therefore, the Court held that the drug company was limiting the market by relying only on one way of processing the product.

There is also a danger of prioritizing consumer welfare under competition rules. How efficiently an undertaking can get away with its abusive behavior and what impact such conduct would have on consumer benefits, should be the analysis criteria for such abusive conduct. However, as Etro ${ }^{57}$ suggests that if the pro-consumer benefits of a dominant undertaking are significant, there is a greater possibility that such undertaking will be immune from liability under competition law. The rationale is that a company having a high market share will constantly be under pressure to create better products and offer lower prices in order to avoid the development and supply of new and more attractive offers from potential competitors. A good example is iPod by Apple which has almost replaced MP3 players. Thus, market developments can be radical and fast compelling the aggressive behavior of dominant powers. How may the aggressive activity of a dominant undertaking affect consumer interests, can be understood from the fact that a dominant company is capable of reducing demand for the other competitors in the market. This is what any aggressive or pro-competitive strategy would do. As argued earlier, exclusionary practices are well known ways of dominant undertakings to restrain competition and discourage competitors.

Under the Regulations of 2008, any non-contractual barrier that restrains consumers from switching to another trader ${ }^{58}$ or significantly impairs or is likely to significantly impair the average consumers' freedom of choice ${ }^{59}$ will be considered as aggressive behaviour of that undertaking. Also any behaviour that influences the consumers to

\footnotetext{
${ }^{56}$ See Cases 6 and 7/73, Commercial solvents v Commission [1974] ECR 223.

${ }^{57}$ See Etro, Federico, The EU Approach to Abuse of Dominance, U.C.S.C. Department of Economics, ECG and INTERTIC ( International Think-tank on Innovation and Competition), Milan, February 2006. Available at www.intertic.org Last accessed on 20.06.2014.

${ }^{58}$ S. 7(2) (d).

${ }^{59}$ S. 7(1) (a).
} 
make decision about a product which they would not make otherwise ${ }^{60}$, will be considered as aggressive behaviour. Moreover, in exercising such behaviour, the meaning of undue influence includes exploitation by the undertaking of its position of power that significantly limits the consumers' ability to make an informed decision $^{61}$.

Ramsay believes that the question whether consumers may be deceived or otherwise harmed if competition regulation is not there, is to be determined by courts. Dominant undertakings would tend to see the regulations as a trade barrier. However, it is the duty of states to justify the regulations in terms of consumer protection.

The only good impact of dominant undertakings' behavior in market on consumers can be that sometimes prices can be low for them. Otherwise, the broad effects are generally disadvantageous. Predatory prices, though low, is in fact designed for a short term so that competitors can be driven out of the market. The prices can be raised later on. Considering the above discussion, it may be concluded that consumers, for several reasons, are actually trapped in dominance over market.

One reason that is widely recognized for such failure is believed to be absence of clarity in EU legislation regarding the impact of market power abuse on consumer rights. It is alleged that the EU competition legislations do not articulate provisions that are clear enough to understand or test every such issue. Also, how consumer rights protection will be guaranteed in a market power abuse condition is a vague idea in the relevant laws. As such, it cannot be said what is the minimum requirement of market practice by undertakings taking consumer rights into consideration or what should be the limit of consumer rights protection in such respect.

As per the European Commission notice on the Application of Art. 81 (now Art.101, TFEU), there are few occasions when direct references to consumer detriments or consumer benefits are laid down in EU soft law. The Commission regrettably specifies that due to lack of emphasis on this area of law, restrictions of competition cannot be regulated with adequate firmness. The Commission also believes that:

"... restrictions of competition by object such as price fixing and market sharing reduce output and raise prices, leading to a misallocation of resources, because goods and services demanded by customers are not produced."

However, the basic question is to what extent and how freely the consumers are able to exercise their rights in the market. Relevant to that are the issues of market

\footnotetext{
${ }^{60}$ S. 7(2) (c).

${ }^{61}$ S. 7(3) (b).
} 
conditions compelling consumers to tolerate the abuse and whether consumers themselves are to blame.

\section{What can be done}

The following may be considered in making the market environment better for consumer protection against abuse of dominance:

1. The terms- 'abuse', 'dominance or market power', 'consumer', 'consumer protection or detriment' - need to have particular standards of interpretation where they come into issues in relation to competition law. Though it is a clear idea that in case of conflict between domestic and EU law, the interpretation at the EU level will prevail, there is still need for a standard or test through which this has to be done. Also, market power has to be defined and interpreted from an objective point of view where sometimes the courts and authorities have to look beyond the original proceeding and find the commercial objective of undertakings.

2. As suggested in the study, in most cases issues like pricing, branding, freedom of choice have significant impacts on consumer interests. Thus, taking these particular abuses or issues into consideration, separate regulatory and administrative bodies may be established at EU and domestic levels.

3. The competition authorities must carefully consider the clearance of any alleged conduct of an undertaking. There is a risk that a dominant undertaking may obtain a favourable clearance that is potentially beneficial to them and for the market but may not be justified on consumer protection grounds. ${ }^{62}$

4. Proper remedies must be ensured at all times in all cases of consumer detriment caused by abuse of market power. Such remedies should be given in a form that constitutes deterrence for other dominant undertakings in the market. Efficiencies of law, systems and proceedings must be tested and reported.

${ }^{62}$ See O’Neill, Aidan, EU Law for UK Lawyers, 2011, Bloomsbury Publishing, p. 1936. 


\section{Conclusion}

Every consumer is different and therefore it is not possible to reach consumer expectation fully in a highly commercialized market. What can reasonably be expected is a system of control: a system that will uphold the balance between market practices and consumer interests. Despite a long series of efforts, legislations and research, it is still argued that consumer interests are being violated by dominant undertakings in the market. Complaints that they fix prices, narrow down the market, mislead consumers are still reported. This proves that the system needs to be even stricter when issues of competition involve issues of consumer protection. Thus, competition law should focus more on socio-economic, political and global aspects of commerce and economy and not just on the market. 